\title{
FIELD EVALUATION OF PROMISING FABA BEAN, Vicia faba L. GENOTYPES TO COWPEA APHID, Aphis craccivora KOCH. INFESTATION AND YIELD PERFORMANCE AT KAFR EL-SHEIKH REGION \\ Nassef, A.M.*; M.A.Khattab*and R.A.I. Abou Mostafa** \\ * Piercing and Sucking Insect Section, Plant Protection Research Institute, ARC, Egypt \\ ** Food Legumes Research Section, Field Crops Research Institute, ARC, Egypt.
}

\section{ABSTRACT}

Two field experiments were conducted at Sakha Agricultural Research Station to evaluate eleven faba bean genotypes compared with the commercial recommended cultivar Sakha 3 for resistance to cowpea aphid, Aphis craccivora Koch. and high yielding ability under two sowing dates during two seasons; 2005/06 and 2006/07. Results revealed that the lines 1561/492/2002 and 96/67/02 are considered promising genotypes in early plantation because they exhibit relative resistance to aphid, but with a high yielding potential. On the other hand, the lines $1561 / 492 / 2002$ and $81 / 35 / 02$ were suitable to optimum plantation date and/or early sowing date if there was an urgent need. Also, results of genotypes reactions to aphid infestation and yield performance proved that the genotypes: 1561/492; 1571/638, $81 / 35$ and $1618 / 846$ were promising for aphid resistance and yielded $2.72 \%$ more than the recommended cultivar Sakha 3. Thus, these promising genotypes could be involved in breeding programs as a source of resistance to cowpea aphid, $A$. craccivora

\section{INTRODUCTION}

Faba bean, (Vicia faba L.) ranks the first among the food legume crops in Egypt, due to its high nutritive value for human beings and their demostic animals. The average cultivated area devoted to faba bean represented 216,000 fedans with an average seed yield of 9.0 ardab/fed., and about $85 \%$ of total area grown with faba bean is located in northern parts of Egypt*. Because rice crop is now harvested earlier than normal, the land after rice, can receive winter crops by the beginning of October. Accordingly, the growers tend to cultivate faba bean early in October, while the recommended sowing date for the commercial cultivars is the first half of November (Amer et al., 1992). Under this early sowing, the seed yield is significantly reduced because of its high infestation with insects; diseases and abnormal environmental conditions.

Cowpea aphid, Aphis craccivora Koch. is considered as one of the most harmful and widespread pests attacking faba bean allover the country. Since 1991/92 season, aphids severely attack the crop causing considerable yield losses (Bishara, 1993). Also, El-Defrawi and Abd El-Azim (1992) reported that the infestation with $A$. craccivora. caused $23.4-53.5 \%$ losses in faba bean yield. Sowing date is one of the main agronomic practices that can directly affect the level of insect infestation (Dent,19991). Therefore, the damage caused by aphids and foliar diseases in north parts of Egypt could 
be minimized if the proper genotype was selected and sown on the proper date, (Amer et al.,1992; Hussein et al.,1994 and El-Deeb et al.,2006.).

In general, the strategy of pest control on different crops must be developed without using insecticides to avoid their hazardous effects. However, resistant entries appear to become one of the most promising alternatives as reported by Ahmed (1994) and Abd El-Galil et al. (2001). Also, sowing date plays an important role in cultural control as mentioned previously. So, the objective of this work was to evaluate eleven faba bean genotypes for resistance to aphid with high yield performance under two sowing dates in North Delta during two successive seasons 2005/06 and 2006/07.

* Minstry of Agriculture and Land Reclamation, Center Adminstration for Agricultural Economic Statistics, Statistical field 2006/07 to seed and straw yield.

\section{MATERIALS AND METHODS}

Field experiments were conducted at the experimental farm of Sakha Agricultural Research Station to evaluate eleven faba bean genotypes in addition to the local cultivar, Sakha 3 to aphid infestation and high yield ability, under early and optimum sowing date during two seasons; 2005/06 and 2006/07. The tested genotypes (listed in Table 1) were supplied by National Legumes Research Program at Sakha Agric. Res. Station. Early sowing date (ES) was done on the first of October and the recommended sowing date (OS) was on the first half of November in the two growing seasons. Each genotype, in addition to Sakha 3, was replicated three times in a complete randomized block design for each sowing date. Each experimental plot consisted of four ridges, $60 \mathrm{~cm}$ apart and three meters long. Planting took place on both sides of ridge, in double seeded hills, $20 \mathrm{~cm}$ apart.

Conventional agricultural practices were performed without any pesticidal treatments throughout the growing seasons. To determine the aphid number (Aphis craccivora Koch. ), weekly samples of ten branches each was randomly chosen from each plot and the numbers of all stages (adults and nymphs) were visually counted in the field, with the aid of hand lens. The inspection began six weeks after sowing and continued till the end of the season. Resistance status of each faba bean genotype was depended on the general mean number of Aphid, A. craccivora. $(\bar{X})$ and the standard deviation (SD) as reported by Chang and Talekar (1980). Genotypes that had mean number of insects more than $\bar{X}+2 S D$, were considered highly susceptible (HS); between $\overline{\mathrm{X}}$ and $\overline{\mathrm{X}}+2 \mathrm{SD}$, susceptible (S); between $\overline{\mathrm{X}}$ and $\overline{\mathrm{X}}-1 \mathrm{SD}$, low resistant (LR); $\overline{\mathrm{X}}-1 \mathrm{SD}$ and $\overline{\mathrm{X}}-2 \mathrm{SD}$, moderately resistant (MR) and less than $\bar{X}-2 S D$, were considered highly resistant $(\mathrm{HR})$. The obtained data were statistically analyzed using $F$ test, and means were compared according to Duncan's Multiple Range Test (Duncan,1955). With respect to seed yield and some of its components, five individuals guarded plants were taken randomly at harvest from each experimental plot. The seed yield/plant 
(g) and 100-seed weight (g) were determined. Also, seed yield (ardab/feddan) was estimated on the basis of yield and area per plot. Reaction to aphid infestation was assessed and recorded under field conditions overall seasons and sowing dates. All data were subjected to standard analysis of variance procedures (Snedecor and Cochran, 1982). Also, the combined analysis was done for the data of both seasons according to Cochran and Cox (1957).

Table (1): Pedigree of 11 faba bean genotpes evaluated to aphid infestation at Sakha Agricultural Research Station during 2005/06 and 2006/2007seasons.

\begin{tabular}{|c|c|}
\hline Cross & Designation \\
\hline $1561 / 492 / 2002$ & Cross $1001 \times$ Cross 958 \\
\hline $1566 / 574 / 2002$ & ILB4370 x Giza 461 \\
\hline $1751 / 638 / 2002$ & ILB4350 x Giza 461 \\
\hline $1618 / 837 / 2002$ & Giza Blanca x Cross 711/778/90 \\
\hline 73/27/2002 & Cross $31 / 105 / 93$ x Giza 3 line 6/25 \\
\hline $81 / 38 / 2002$ & Early line of Sakha1x Giza3 line 6/25 \\
\hline $92 / 59 / 2002$ & Cross $6 / 1148 / 94 \times$ cross $8 / 1156 / 44$ \\
\hline $96 / 67 / 2002$ & Hamman $5 \times$ cross $8 / 1156 / 94$ \\
\hline $1610 / 705 / 2002$ & Giza Blanca $x$ cross $735 / 827 / 90$ \\
\hline $1618 / 846 / 2002$ & Giza Blanca $x$ cross $711 / 778 / 90$ \\
\hline Sakha 1 x Sakha 3 & Giza $716 \times$ 620/283/85 x Giza 716x 620/283/85 \\
\hline Sakha3 & Local variety (Giza $461 \times 503 / 453 / 83$ \\
\hline
\end{tabular}

\section{RESULTS AND DISUSSION}

\section{1- Resistance status of tested faba bean genotypes against Aphis} craccivora Koch. infestation in relation to yield.

Data presented in Tables (2\&3) exhibit the average number of aphids /10 shoots; susceptibility degree (SD) of the tested faba bean genotypes to aphid infestation and seed yield (ardab / feddan) during 2005/06 and 2006/07 growing seasons as affected by two sowing dates (first of Octobers and the first half of November) statistical analysis of data revealed highly significant differences between all tested faba bean genotypes of each sowing date in both seasons.

It was apparent that the mean number of aphid was higher in the first season than in the second one at two sowing dates; 22.6 and 2.79 aphids/10 shoots in the early sowing (ES) and (OS) 6.07 and 5.5 aphids/10shoots, respectively

Also, the general mean of aphid at (ES) was higher than (os) by 12.70 and 5.78 aphid $/ 10$ shoots overall growing seasons. This may be attributed to the differences in environmental conditions or to other factors as mentioned by Kumar,1984. who revealed that certain environmental conditions can influence fundamental physiological processes of the plant as well as the pest. Thus, a variety that exhibits resistance in one locality or environment may be susceptible in another. Also, Metcalf and William (1975) reported that certain environmental conditions may alter the physiology of the plant to the extent that it becomes unsuitable as a host for certain pests. 
Nassef, A.M. et al.

Table (2): Average number of aphids/10 shoots, susceptibility degree (SD) and seed yield of faba bean genotypes affected by early sowing date (ES) (first of October) at at Kafr El-Sheikh region.

\begin{tabular}{|c|c|c|c|c|c|c|c|c|}
\hline \multirow[b]{2}{*}{ Genotype } & \multirow[b]{2}{*}{$2005 / 06$} & \multirow[b]{2}{*}{ SD } & \multirow[b]{2}{*}{ 2006/07 } & \multirow[b]{2}{*}{ SD } & \multicolumn{4}{|c|}{ Average of both seasons } \\
\hline & & & & & aphid & SD & $\begin{array}{c}\text { Seed } \\
\text { yield } \\
\text { ard/fed }\end{array}$ & $\begin{array}{c}\text { Yield * } \\
\text { adavlage } \%\end{array}$ \\
\hline $1561 / 492 / 2002$ & 10.7 & LR & 1.4 & LR & 6.05 ef & LR & 10.09 cde & +4.24 \\
\hline $1566 / 574 / 02$ & 9.6 & LR & 0.2 & LR & $4.9 f$ & $\mathrm{MR}$ & $9.42 d-g$ & -2.69 \\
\hline $1571 / 638 / 02$ & 44.9 & $\mathrm{~S}$ & 6.5 & $\mathrm{~S}$ & $25.7 a$ & S & $11.28 \mathrm{a}$ & +16.53 \\
\hline $1618 / 837 / 02$ & 7.5 & MR & 2.0 & LR & $4.75 f$ & MR & $8.88 f g$ & -8.26 \\
\hline $73 / 27 / 02$ & 30.2 & $\mathrm{~S}$ & 4.8 & $\mathrm{~S}$ & $17.5 b$ & $\mathrm{~S}$ & $9.00 \mathrm{efg}$ & -7.02 \\
\hline $81 / 35 / 02$ & 18.4 & LR & 0.7 & LR & $9.55 \mathrm{cde}$ & LR & $9.95 \mathrm{cde}$ & +2.78 \\
\hline $92 / 59 / 02$ & 15.7 & LR & 0.3 & LR & 8.0 def & LR & $8.63 \mathrm{~g}$ & -10.85 \\
\hline $96 / 67 / 02$ & 10.7 & LR & 12.3 & $\mathrm{HS}$ & $11.5 \mathrm{~cd}$ & LR & $10.12 \mathrm{bcd}$ & +4.55 \\
\hline $1610 / 705 / 02$ & 38.8 & $S$ & 0.5 & LR & $19.65 b$ & $\mathrm{~S}$ & $10.92 \mathrm{ab}$ & +12.81 \\
\hline $1618 / 846 / 02$ & 22.0 & LR & 2.4 & LR & $12.2 \mathrm{c}$ & LR & $10.74 a b c$ & +10.95 \\
\hline Saka 1 x Saka & 45.9 & $\mathrm{~S}$ & 1.4 & LR & $23.65 a$ & $\mathrm{~S}$ & $9.18 d-g$ & -5.17 \\
\hline Saka 3 & 16.8 & LR & 1.0 & LR & $8.9 \mathrm{cde}$ & LR & 9.68def & - \\
\hline Mean & 22.60 & & 2.79 & & 12.70 & & 9.82 & \\
\hline \pm & \pm & & \pm & & \pm & & \pm & \\
\hline $\mathrm{Sd}^{*}$ & 13.95 & & 3.55 & & 7.24 & & 0.85 & \\
\hline F values & $54.822^{\star \star}$ & & $704.93^{\star \star}$ & & $57.315^{\star \star}$ & & $7.35^{\star \star}$ & \\
\hline
\end{tabular}

${ }^{\star}$ yield advantage compared with the recommended cultivar, Sakha3

Table(3): Average number of Aphids/10shoots, susceptibility degree (SD) and seed yield of faba bean genotypes sown in recommended date (OS) (first half of November) at Kafr ElSheikh region.

\begin{tabular}{|c|c|c|c|c|c|c|c|c|}
\hline \multirow[b]{2}{*}{ Genotypes } & \multirow[b]{2}{*}{$2005 / 06$} & \multirow[b]{2}{*}{ SD } & \multirow[b]{2}{*}{$2006 / 07$} & \multirow[b]{2}{*}{ SD } & \multicolumn{4}{|c|}{ Average of both seasons } \\
\hline & & & & & aphid & SD & $\begin{array}{c}\text { Seed } \\
\text { yield } \\
\text { ard/fed }\end{array}$ & $\begin{array}{c}\text { Yield* }^{\star} \\
\text { adavlage } \%\end{array}$ \\
\hline 1561/492/2002 & 4.3 & LR & 3.7 & LR & 4.00 ef & LR & $14.4 \mathrm{a}$ & +4.72 \\
\hline $1566 / 574 / 02$ & 3.3 & MR & 1.5 & MR & $2.40 f$ & MR & 12.19def & -11.35 \\
\hline $1571 / 638 / 02$ & 6.5 & $S$ & 2.9 & LR & $4.72 \mathrm{de}$ & LR & 13.15a-e & -4.36 \\
\hline $1618 / 837 / 02$ & 3.7 & MR & 7.0 & S & $5.35 \mathrm{cde}$ & LR & $12.38 c-f$ & -9.96 \\
\hline $73 / 27 / 02$ & 8.1 & $\mathrm{~S}$ & 5.2 & LR & $6.65 \mathrm{bc}$ & $S$ & $13.44 a-d$ & -17.71 \\
\hline $81 / 35 / 02$ & 7.5 & $S$ & 4.9 & LR & $6.2 \mathrm{bcd}$ & S & $13.97 a b$ & +1.6 \\
\hline $92 / 59 / 02$ & 8.1 & S & 9.6 & $S$ & $8.85 a$ & $\mathrm{~S}$ & 12.27def & -10.76 \\
\hline $96 / 67 / 02$ & 6.7 & $\mathrm{~S}$ & 2.8 & LR & $4.75 \mathrm{de}$ & LR & $12.46 \mathrm{def}$ & -9.38 \\
\hline $1610 / 705 / 02$ & 5.0 & LR & 10.1 & $S$ & $7.55 \mathrm{ab}$ & $S$ & 12.10ef & -12.00 \\
\hline $1618 / 846 / 02$ & 7.6 & $S$ & 10.1 & S & $8.8 a$ & $S$ & $12.72 a-f$ & -7.49 \\
\hline Saka 1 x Saka & 4.9 & LR & 4.4 & LR & $4.65 \mathrm{de}$ & LR & $11.65 f$ & -15.27 \\
\hline Saka 3 & 7.1 & $\mathrm{~s}$ & 3.9 & $\mathrm{LR}$ & $5.5 \mathrm{cde}$ & LR & $13.75 a b$ & - \\
\hline Mean & 6.07 & & 5.50 & & 5.78 & & 12.84 & \\
\hline \pm & \pm & & 00 & & \pm & & \pm & \\
\hline $\begin{array}{c}\text { Sd }^{\star} \\
\text { F values }\end{array}$ & $\begin{array}{c}1.74 \\
12.539^{\star *}\end{array}$ & & $\begin{array}{c}2.98 \\
18.138^{\star *}\end{array}$ & & $\begin{array}{c}1.93 \\
13.879^{\star *}\end{array}$ & & $\begin{array}{c}0.75 \\
6.93^{\star \star}\end{array}$ & \\
\hline
\end{tabular}

* yield advantage compared with the recommended cultivar, Sakha3 
Depending on the general mean number and (SD) value, the used statistical methods enabled to classify the tested faba bean genotypes into various categories of resistance. Regardless the growing seasons, the (ES) plantations of faba bean genotypes 1571/638; 73/27; 1610/705 and Sakha1 x Sakha3 appeared as susceptible (S) genotypes as they exhibited the highest number of insects; $25.7 ; 17.5 ; 19.65$ and 23.65 aphids/10 shoots, respectively. The lines 1566/574 and 1618/837 appeared moderately resistant (MR) to aphid because they harbored the lowest number (4.9 and 4.75 aphids/10shoots)

The remaining lines which harbored quietly low numbers showed some sort of resistance, where lines 1561/492, 81/35, 92/59,96/67, 1618/846 and the recommended cultivar Sakha 3 appeared as low resistant (LR).On the other hand, the (OS) plantations of tested faba bean genotypes took a similar trend of susceptibility. It was found that the lines 1561/492 and 96/67 and the cultivar Sakha 3 appeared as low resistant (LR) as in (ES) plantation. However,1566/574 appeared moderately resistant (MR), while 1610/705 appeared as susceptible (S) genotypes at two sowing dates in both seasons. The rest genotypes showed variable levels of resistance to aphid infestation. These results allow plant breeders to select genotypes having resistance levels satisfactory for breeding purposes. These variations in genotypes susceptibility to aphid infestation caused by insect pest may be due to the presence of antixenoses (non preference) and /or antibiosis phenomena, as described by Van Edmen (1987) who indicated that the antixenotic plant can be avoided or less colonized by pests seeking for food or oviposition sites. With respect to seed yield (ardab/ feddan), statistical analysis of the data revealed highly significant differences among all tested genotypes for two sowing dates. As for (ES) plantation, the breeding lines 1571/638; 1610/705;1618/846; 96/67; 1561/492 and 81/35 represented significant increases by $16.53 ; 12.81 ; 10.95 ; 4.55,4.24$ and $2.78 \%$ respectively compared to the recommended cultivar Sakha 3. On the other hand, the lines $1561 / 492$ and $81 / 35$ yielded 4.72 and $1.6 \%$ more than Sakha 3 when sown at the recommended date, during both seasons. Thus $1561 / 492$ and $81 / 35$ genotypes could be recommended to be cultivate in early or optimum sowing date. In general, the lines 1561/492 and 96/67 are considered as promising in early plantation because they exhibit low resistance for aphids and exceed the yielding ability. On the other hand, the lines 1561/492 and 81/35 were suitable to optimum plantation and/ or early sowing date if there was an urgent need. Also, the lines 1561/492 and 96/67 are considered promising in early plantation because they exhibit relative resistance to aphids infestation with high yielding ability. So, this work may be considered as an initial effort to determine the relative susceptibility and resistance degree of certain Egyptian faba bean genotypes to aphid with high yield potential, but more work is still needed to reveal some other reasons responsible for resistance in faba bean genotypes. Consequently, additional serious trials must be done to transfer gene (s) responsible for this phenomenon to newly produced faba bean genotypes. 


\section{2-Interaction effects:-}

Mean number of aphid, A. craccivora per ten shoots; seed yield (ardab/fed.);seed yield/plant (g)and 100- seed weight $(\mathrm{g})$ as affected by sowing date; seasons and tested genotypes are presented in Table (4). Results showed that both mean number of Aphids and seed yield (ardab/fed.) were significantly affected by sowing dates. Numbers of aphids infesting different genotypes are higher in the early plantation than in the optimum one. This may due to the difference in weather factors and/or natural enemies. Obtained results agree with those of El-Heneidy et al. (1988) who reported that aphid population was relatively greater in early sowing date than in late sown one. Also, El-Galaly et al. (2008) proved that the aphid numbers were significantly lower in the late sowing date (November ${ }^{1 s t}$ ) in two studied seasons compared to that sown on the first of October. In contrast, Kalafalla and El-Galaly (1998) and El-Samahy (2008) reported that faba bean sown in November received the highest number of aphids, while that sown in October harbored the lowest number.

With respect to seed yield (ardab/fed), the estimated mean value was significantly higher in (os) (12.84 ardab) than that recorded at (ES) (9.82 ardab) with an advantage of $30.75 \%$. Data revealed that seed yield/plant $(\mathrm{g})$ and 100-seed weight $(\mathrm{g})$ were insignificantly affected by aphid infestation in both sowing dates. This may be due to other characters (eg No.of branches or pods). The seasons affect significantly all characters under study with conspicuous increase in yield component in contrast with little aphid infestation.

All yield components and aphid infestation were highly significantly affected by tested genotypes. Although some genotypes were liable to high aphid population during the main growth stages, they recorded high estimates of seed yield (ardab/ fed.). Among these genotypes, 1571/638/02, $81 / 38 / 02$ and 1618/846/02 represented significant increases of $4.63,2.49$, $0.51 \%$. These results agree with those of El-Defrawi et al. (2007). It is worth to mention that the character of tolerance to aphid attack did not necessarily mean that the cultivar gives the highest yield, but mainly exhibit less damage throughout unsuitability for build up of aphid population. (Bond \& Lowe, 1975 and El-Defrwi\& Bishara 1992) as in case of 1571/638/02 represented 12.21 ardab/fed, although it was liable to high aphid population.

Also, it was noticed that the line 1561/492/2002 was superior to the check Sakha 3 as it was less liable to aphid infestation and with more seed yield (ardab/fed.) with increase of $3.26 \%$. The ability to aphid infestation is most probably due that chemical composition of plants is of fundamental significance in their food acceptance or rejection by insects. This is true with regard to selection between different plant species (Hsiao and Fraenkel 1968) or by interfering with host-selection stimuli such as leaf sahape and colour (Klingauf, 1982). 
Table (4): Effect of sowing dates, seasons and faba bean genotypes on aphid infestation and yield parameters.

\begin{tabular}{|c|c|c|c|c|}
\hline Effect & $\begin{array}{l}\text { Mean numbers of } \\
\text { Aphids/10 shoots }\end{array}$ & $\begin{array}{l}\text { Seed yield } \\
\text { ardab/fed }\end{array}$ & $\begin{array}{c}\text { Seed } \\
\text { yield/plant }(g)\end{array}$ & $\begin{array}{c}100 \text {-seed } \\
\text { weight }(\mathrm{g})\end{array}$ \\
\hline Sowing date & * & ** & NS & NS \\
\hline (ES) & 12.70 & 9.82 & 22.72 & 80.64 \\
\hline (os) & 5.78 & 12.84 & 23.16 & 77.17 \\
\hline L.S.D (0.05) & 3.43 & 0.572 & 4.641 & 15.72 \\
\hline Seasons & ** & ** & ** & $\star \star \star$ \\
\hline $2005 / 06$ & 14.34 & 8.08 & 17.06 & 75.71 \\
\hline $2006 / 07$ & 4.14 & 14.58 & 28.82 & 82.21 \\
\hline $\begin{array}{l}\text { L.S.D(0.05) } \\
\text { Genotypes }\end{array}$ & 0.311 & 2.66 & 3.38 & 1.851 \\
\hline $1561 / 492 / 2002$ & 5.03 & 12.05 & 21.46 & 78.58 \\
\hline $1566 / 574 / 02$ & 3.65 & 10.81 & 19.92 & 76.17 \\
\hline 1571/638/02 & 15.20 & 12.21 & 21.58 & 80.58 \\
\hline $1618 / 837 / 02$ & 5.05 & 10.63 & 25.81 & 80.92 \\
\hline 73/27/02 & 12.08 & 11.22 & 20.57 & 74.25 \\
\hline $81 / 35 / 02$ & 7.88 & 11.96 & 24.72 & 80.59 \\
\hline $92 / 59 / 02$ & 8.43 & 10.45 & 21.31 & 80.50 \\
\hline 96/67/02 & 8.13 & 11.24 & 23.17 & 79.84 \\
\hline $1610 / 705 / 02$ & 13.60 & 11.51 & 24.51 & 79.59 \\
\hline 1618/846/02 & 10.50 & 11.73 & 22.18 & 78.75 \\
\hline Saka 1 x Saka & 14.15 & 10.41 & 25.37 & 75.42 \\
\hline Saka 3 & 7.20 & 11.67 & 24.66 & 81.42 \\
\hline L.S.D (0.05) & $1.551^{\star \star}$ & $0.614^{\star \star}$ & $2.125^{\star \star}$ & $3.698^{\star \star}$ \\
\hline
\end{tabular}

The interaction effect between genotypes and two sowing dates on aphid infestation and seed yield (ardab/fed.) is given in Table (5). Data revealed that four and six genotypes were lower infested with aphid than the recommended cultivar Sakha 3 in early and optimum plantations, respectively.

Table (5): Average number of aphid and seed yield (ardab/fed.) of some faba bean genotypes affected by different sowing dates.

\begin{tabular}{|c|c|c|c|c|}
\hline \multirow[t]{2}{*}{ Genotype } & \multicolumn{2}{|c|}{$\begin{array}{l}\text { Mean number of } \\
\text { aphids/10shoots }\end{array}$} & \multicolumn{2}{|c|}{ Seed yield ardab/fed } \\
\hline & (ES) & (OS) & (ES) & (OS) \\
\hline $1561 / 492 / 2002$ & 6.05 & 4.00 & 9.96 & 14.40 \\
\hline $1566 / 574 / 02$ & 4.90 & 2.40 & 9.42 & 12.19 \\
\hline $1571 / 638 / 02$ & 25.7 & 4.70 & 11.28 & 13.15 \\
\hline $1618 / 837 / 02$ & 4.75 & 5.35 & 8.88 & 12.38 \\
\hline 73/27/02 & 17.50 & 6.65 & 9.00 & 13.44 \\
\hline $81 / 35 / 02$ & 9.55 & 6.20 & 9.95 & 13.97 \\
\hline 92/59/02 & 8.0 & 8.85 & 8.63 & 12.27 \\
\hline $96 / 67 / 02$ & 11.5 & 4.75 & 10.12 & 12.46 \\
\hline 1610/705/02 & 19.65 & 7.55 & 10.92 & 12.10 \\
\hline 1618/846/02 & 12.2 & 8.80 & 10.74 & 12.72 \\
\hline Saka 1 x Saka & 23.65 & 4.65 & 9.18 & 11.65 \\
\hline Saka 3 & 8.9 & 5.50 & 9.68 & 13.65 \\
\hline \multirow{2}{*}{$\begin{array}{c}\text { Mean } \\
\text { L.S.D (0.05) }\end{array}$} & 12.70 & 5.78 & 9.82 & 12.84 \\
\hline & \multicolumn{2}{|c|}{$3.43,0.572$} & & \\
\hline
\end{tabular}


Concerning to seed yield (ardab/fed), six genotypes (1561/492; 1571/638; $81 / 35 ; 96 / 67,1610 / 705$ and $1618 / 846$ in the early plantation and two (1561/492 and 81/35) in the optimum one recorded the highest estimate of seed yield (ardab/fed.). The genotypes 1571/638 and 1561/492 significantly outyielded the recommended cultivar Sakha 3 by $16.35 \% ; 5.5 \%$ in (ES) and (OS) plantation allover two seasons, respectively.

The interaction effect between all tested faba bean genotypes and seasons on aphid infestation and seed yield (ardab/fed.) is presented in Table (6). Results showed that some tested genotypes was significantly less infested with aphid compared to the recommended cultivar Sakha 3 in the first season. Regarding to the seed yield (ardab/fed.), all genotypes did not differ significantly at $5 \%$ level although four genotypes 1561/492; $1571 / 638 ; 81 / 35$ and 1618/846 recorded high estimates of seed yield (ardab/fed.) in both seasons.

Table (6): Average number of some faba bean genotypes affected by growing seasons.

\begin{tabular}{|l|c|c|c|c|}
\hline \multirow{2}{*}{ Genotype } & $\begin{array}{c}\text { Mean number of aphids/ 25 } \\
\text { shoots }\end{array}$ & \multicolumn{2}{c|}{$\begin{array}{c}\text { Seed yield } \\
\text { ardab/fed }\end{array}$} \\
\cline { 2 - 5 } & $\mathbf{2 0 0 5 / 0 6}$ & $\mathbf{2 0 0 6 / 0 7}$ & $\mathbf{2 0 0 5 / 0 6}$ & $\mathbf{2 0 0 6 / 0 7}$ \\
\hline $\mathbf{1 5 6 1 / 4 9 2 / 2 0 0 2}$ & 7.50 & 2.55 & 8.88 & 15.22 \\
$\mathbf{1 5 6 6 / 5 7 4 / 0 2}$ & 6.45 & 0.85 & 7.58 & 14.04 \\
$\mathbf{1 5 7 1 / 6 3 8 / 0 2}$ & 25.70 & 4.70 & 8.99 & 15.44 \\
$\mathbf{1 6 1 8 / 8 3 7 / 0 2}$ & 5.60 & 4.50 & 7.35 & 13.91 \\
$\mathbf{7 3 / 2 7 / 0 2}$ & 19.15 & 5.00 & 7.98 & 14.45 \\
$\mathbf{8 1 / 3 5 / 0 2}$ & 12.95 & 2.80 & 8.65 & 15.27 \\
$\mathbf{9 2 / 5 9 / 0 2}$ & 11.90 & 4.95 & 7.15 & 13.75 \\
$\mathbf{9 6 / 6 7 / 0 2}$ & 8.70 & 7.55 & 8.11 & 14.47 \\
$\mathbf{1 6 1 0 / 7 0 5 / 0 2}$ & 21.90 & 5.30 & 8.29 & 14.74 \\
$\mathbf{1 6 1 8 / 8 4 6 / 0 2}$ & 14.80 & 6.20 & 8.53 & 14.93 \\
Saka 1 x Saka & 25.4 & 3.0 & 7.03 & 13.80 \\
Saka 3 & 11.95 & 2.45 & 8.42 & 14.92 \\
\hline \multicolumn{1}{|c|}{ Mean } & 14.34 & 4.14 & 8.08 & 14.58 \\
\hline L.S.D (0.05) & $\mathbf{0 . 3 1 1 , 2 . 6 6}$ & \multicolumn{3}{|c|}{} \\
\hline
\end{tabular}

Significant interaction between sowing dates and seasons was detected (Table 7). The higher infestation of aphids was observed at (ES) during 2005/06 and the lower was at the same sawing date in the second season. High estimate of seed yield (ardab/fed.) was recorded at two optimum sowing dates during two study seasons with 9.25 and 16.42 (ardab/fed.) compared to 6.9 and 12.74 (ardab/fed.) at early sowing. The average number of aphid and seed yield (ardab/fed.) were affected by different sowing dates, seasons and genotypes are presented in Table (8). Results indicated that some of the tested genotypes were significantly less infested with aphids compared to the recommended cultivar in both sowing dates during both seasons. This resistance is mainly associated with genetic sources of resistant parental genotypes included in the crosses. Host plant 
resistance in faba bean as a control measure for aphid has been studied for many years by several researchers, however only few cultivars were found resistant (Bond and Lowe;1975; Muller 1958 and Holt, 1982). According to estimates of seed yield (ardab/fed.), some genotypes exceeded the recommended cultivar Sakha 3 at different sowing dates during both seasons. From reviewing the abovementioned results of genotypes, reaction to aphid infestation and yield performance, it could be observed that the fallowing genotypes 1561/492/2002; 1571/638/02; 81/35/02 and $1618 / 846 / 2002$ were promising for aphid resistance and yielded $2.72 \%$ more than the recommended cultivar Sakha3. Results in Table (9) indicated the abovementioned faba bean genotypes exhibited slight increase of seed yield/plant (g) and 100-seed weight per plant (g). it may be due to different genetical sources of yield and resistant against aphid infestation involved in these genotypes

Table (7): Average Aphid infestation and seed yield (ardab/fed.) of faba bean tested genotypes affected by seasons and sowing date.

\begin{tabular}{|c|c|c|}
\hline \multicolumn{3}{|c|}{ Aphid infestation } \\
\hline Seasons & (ES) & (OS) \\
\hline $2005 / 2006$ & 22.6 & 6.07 \\
\hline $2006 / 2007$ & 2.79 & 5.5 \\
\hline L.S.D. at 5\% & \multicolumn{2}{|c|}{$3.43^{\star}$} \\
\hline \multicolumn{3}{|c|}{ Seed yield (ardab/fedan) } \\
\hline Seasons & (ES) & (OS) \\
\hline $2005 / 2006$ & 6.9 & 9.25 \\
\hline $2006 / 2007$ & 12.74 & 16.42 \\
\hline L.S.D. at 5\% & $0.572^{\star \star}$ \\
\hline
\end{tabular}


Nassef, A.M. et al.

8

3938 
J. Agric. Sci. Mansoura Univ., 34 (4), April, 2009

9

3939 


\section{REFERENCES}

Abdel-Galil, F.A., M.A. Morsi, S.H. Mohamed and M.A. Amro. (2001). Control strategy of the lima bean pod borer Etiella zinckenella Treit. Infesting cowpea in the new reclaimed areas. Proceedings of the $1^{\text {st }}$ Congress of Integrated pest Management, Cairo Univ., 1:25-32.

Ahmed, M.A. (1994). Differences in susceptibility of six cucumber cultivars to infestation by Aphis gossypii Glov., Tetranychus unticae and Bemisia tabaci as correlated to protein and amino acid contents of leaves. Ann.Agric.Sci. Moshtohor, 32 (4): 2189-2194.

Amer, M.I., M.A. El-Borai and M.M. Radi. (1992). Response of three faba bean (Vica faba L.) cultivars to three sowing dates under different plant densities in North delta. J. Agric. Res. 18(4): 591-599. Tanta Univ., Egypt.

Bishara, S.A.(1993). Entomology part. $5^{\text {th }}$ Ann. Meeting Nile valley Reg. prog. On call. season food legume, Cairo 12-16 Sept., 1993.

Bond, d.A. and H.J.B. Lowe (1975). Testes for resistance to Aphis faba in field beans (Vica faba L.). Ann. Appl. Biol., 81:21-32.

Chiang, H.S. and N.S.Talekar (1980). Identification of sources of resistance to the beanfly and two agromizd flies in soybeab and mungbean. $J$. Econ. Entomol. 73(2):197-199.

Cochran, W.G. and G.M. Cox. (1957): Experimental Designs, New York.

Dent, D. (1991). Insect Pest Management. C.A.B. International, pp213

Duncan, D.B. (1955). Multiple range and multiple F tests. Biometrics.11;1-42.

El-Deeb, M.A., A.H.A. Hussein, Kh. M. Yamani and T.S.A. El-Marsafawy. (2006). Response of new faba bean genotypes to different sowing dates and plant densities in the New Valley First Field Crops Conf. Proceeding 22-2 Aug. 6:358-362.

El-Deferawi, G.M. and M.A.Aziem (1992). Chemical control of Cowpea aphid, Aphis Craccivora on faba bean crop. Zagazig. J. Agric. Res. Vol. 19 No (6): 2657-2663.

El-Deferawi, G.M. and S.I. Bishara (1992). Resistance to Aphis craccivora Koch. in faba bean. Zagazig J. Agric. Res., 19(6): 2647-2655.

El-Deferawi, G.M.; A.M. El-Gantiry; S. Weigand and S.A. Khalil (1991). Screening of faba bean (Vica faba L.) for resistance to Aphis craccivora Koch. Arab.J. Plant Protection, 9(2): 138-141.

El-Deferawi, G.M. and S.A. Mokhtar (2007). Evaluation of some faba bean (Vica faba L.). Genotypes for resistance to cowpea aphid, Aphis craccivora Koch. Egypt. J. Appl. Sci. 22 (6A): 294-309.

El-Galaly, Ola, A.M., M.I., Amer, Sami A. Mahmoud, N.M. Abou-Zeid and Nagwa, M.A.Mahmoud. (2002). Integrated control of certain falige disease on faba bean (Vicia faba L.) in Egypt. J. Agric. Res. 28(2): $301-$ 311 Tanta Univ., Egypt.

El-Galaly, Ola, A.M., R.A.I. Abou-Moustafa; A.M.Nassef and Nagwa, M.A.Mahmoud (2008). Response of two faba bean (Vica faba L.) promising lines and Sakha3 cultivar to different sowing dates and plant Densities. J. Agric. Res. Kafer El-Sheikh Unv., 34 (3):647-661. 
El-Henediy, A., G. Resk, A.M. Hekal and S. Abdel-Samad. (1998). Impact of planting date on aphid populations and associated natural enemies on faba bean plants in Egypt. Arab J. Plant Protection, 16(2): 55-59.

El-Samahy, M.F.M. (2008). Studies on faba bean aphid, Aphis craccivora and faba bean leafminer, Liriomyza trifolii and natural enemies at Kafr ElSheikh governorate. Ph.D. Thesis, Fac. Agric. Tanta Univ.Egypt.

Holt, J. (1982). Aphid resistance in faba beans. Ph. D. Thesis, Fac. Science Southhampton Univ., England.

Hsiao, T.H. and G. Fraenkel (1968). The role of secondary plant substance in the food specificity of the Colorado potato beetle. Ann. Soc. Am., 61:485-493

Hussein, A.H., R.F. Disautky, M.A. El-Deeb and M.M. El-Morsy. (1994). Effect of sowing dates and plant densities on yield components of new faba bean cultivar (Giza Blanka) in newly reclaimed land. J. Agric. Sci. Mansoura Univ., 19(2): 447-451.

Khalafalla, E.M.E. and Ola, A.M. El-Galaly. (1998). Main insects of faba bean and yield in relation to sowing dates at Kafr el-Sheikh region. J. Agric. Res. Tanta Univ., 24(3): 282-291.

Klingauf, F.A.J. (1982). Breeding for resistance to aphids. In: "Faba Bean Improvement", G. Hawtin and C. Webb (Eds.), ICARDA:285-295.

Kumar, R. (1984). Insect pest control with special reference to African Agriculture. Edward Arnold, London. PP.298.

Metcalf, R.L. and L.H. William ( 1975). Introduction to insect pest management. New York. Pp.587.

Mohamed, H.A. (1982). Major disease problem of faba beans in Egypt in faba bean improvement proceedings of international faba bean conference. Cairo. March. 7-11 pp 213-225.

Muller, H.J. (1958). The behaviour of Aphis fabae inselecting its host plants especially different varieties of Vicia faba. Ent. exp.appl., 1:66-72.

Snedecor, G.W. and W.B. Cochran. (1982). Statistical Methods $7^{\text {th }}$ ed. lowa State Univ. Press, Ames. lowa, U.S.A.

Van Emden, H.F. (1978). Insects and secondary plant substances- an alternative viewpoint with special reference to aphids. In Biochemical Aspects of plant and Animal Co-evolution, pp.309-323.ed. by J.B. harborne. Academic Press, London. 
تقييم بعض التراكيب الوراثية المبشرة من الفول البلدي لصفه المقاومـة لمن اللوبيا

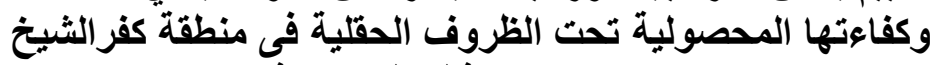

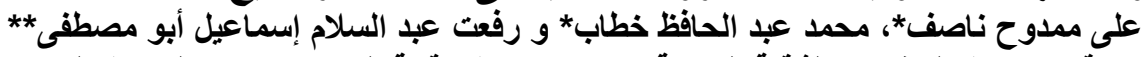

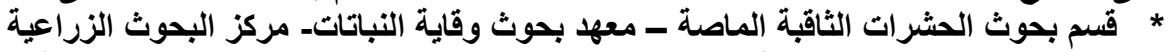

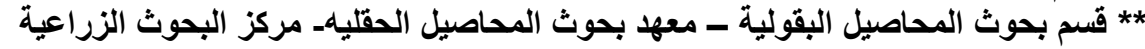

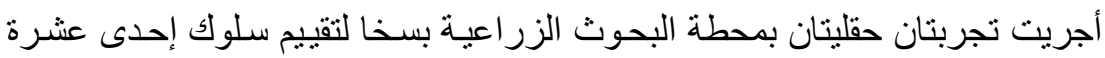

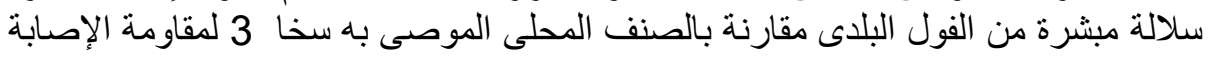

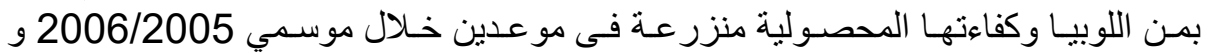
2007/2006

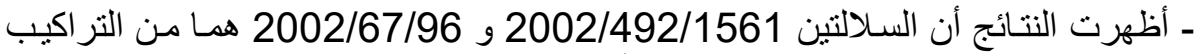
الور اثبة المبشرة للزر اعة المبكرة حيث أظهرت مقاومـة للمن وكفاءة محصولية عالية الئة.

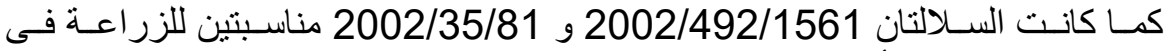

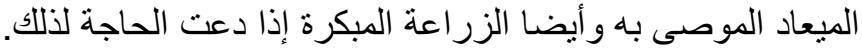

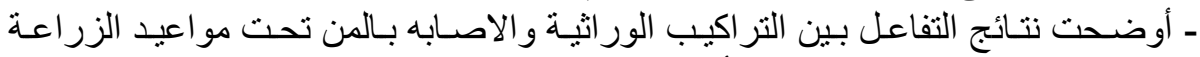

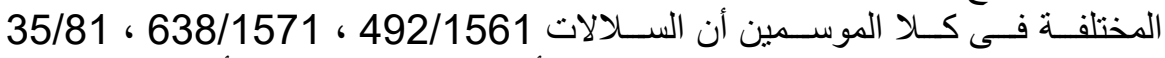

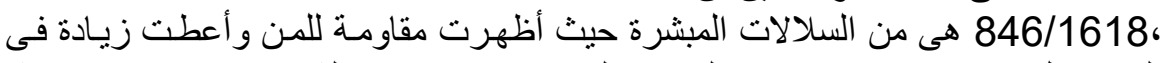

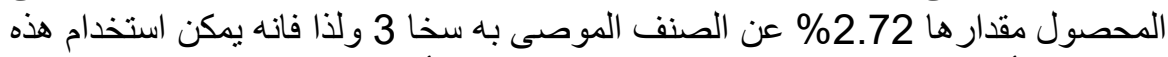

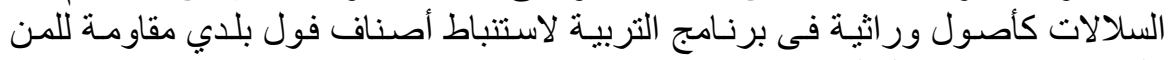
ول ولها صفة الإنتاجية العالية. 
J. Agric. Sci. Mansoura Univ., 34 (4), April, 2009 
Table (8): Mean number of aphid/10shoots and seed yield (ardab/fed.) of some faba bean genotypes during 2005/06 and 2006/07 seasons under two plant dates.

\begin{tabular}{|c|c|c|c|c|c|c|c|c|c|c|c|}
\hline & & & & & & \multirow{2}{*}{\multicolumn{4}{|c|}{ Seed yield ardab/fed. }} & \multirow{4}{*}{ Mean } & \multirow{4}{*}{$\begin{array}{c}\text { Yield }^{\star} \\
\text { advantage } \\
\%\end{array}$} \\
\hline \multirow{3}{*}{ Genotype } & \multicolumn{4}{|c|}{ Mean number of aphids } & \multirow{3}{*}{ Mean } & & & & & & \\
\hline & \multicolumn{4}{|c|}{$2005 / 06$ at $2006 / 07$} & & \multicolumn{2}{|c|}{$2005 / 06$ at } & \multicolumn{2}{|c|}{$2006 / 07$} & & \\
\hline & (ES) & (OS) & $(E S)$ & $(\mathrm{OS})$ & & (ES) & (OS) & (ES) & (OS) & & \\
\hline $1561 / 492 / 2002$ & 10.7 & 4.3 & 1.4 & 3.7 & 5.03 & 7.46 & 10.29 & 12.45 & 17.98 & 12.05 & +3.26 \\
\hline $1566 / 574 / 02$ & 9.6 & 3.3 & 0.2 & 1.5 & 3.65 & 6.34 & 8.81 & 12.50 & 15.57 & 10.81 & -7.37 \\
\hline $1571 / 638 / 02$ & 44.9 & 6.5 & 6.5 & 2.9 & 15.2 & 8.38 & 9.58 & 14.17 & 16.71 & 12.21 & +4.63 \\
\hline $1618 / 837 / 02$ & 7.5 & 3.7 & 2.0 & 7.0 & 5.05 & 5.79 & 8.91 & 11.96 & 15.85 & 10.63 & -8.92 \\
\hline $73 / 27 / 02$ & 30.2 & 8.1 & 4.8 & 5.2 & 12.08 & 5.97 & 9.99 & 12.02 & 16.88 & 11.22 & -3.86 \\
\hline $81 / 35 / 02$ & 18.4 & 7.5 & 0.7 & 4.9 & 7.88 & 7.15 & 10.15 & 12.74 & 17.79 & 11.96 & +2.49 \\
\hline $92 / 59 / 02$ & 15.7 & 8.1 & 0.3 & 9.6 & 8.43 & 5.55 & 8.75 & 11.71 & 15.78 & 10.45 & -10.45 \\
\hline 96/67/02 & 10.7 & 6.7 & 12.3 & 2.8 & 8.13 & 7.19 & 9.03 & 13.05 & 15.88 & 11.24 & -3.68 \\
\hline $1610 / 705 / 02$ & 38.8 & 5.0 & 0.5 & 10.1 & 13.6 & 8.12 & 8.45 & 13.72 & 15.75 & 11.51 & -1.37 \\
\hline $1618 / 846 / 02$ & 22.0 & 7.6 & 2.4 & 10.0 & 10.5 & 7.9 & 9.16 & 13.58 & 16.28 & 11.73 & +0.51 \\
\hline Saka 1xSaka3 & 45.9 & 4.9 & 1.4 & 4.6 & 14.15 & 6.17 & 7.88 & 12.18 & 15.42 & 10.41 & -10.41 \\
\hline Saka 3 & 16.8 & 7.1 & 1.0 & 3.9 & 7.2 & 6.79 & 10.04 & 12. 57 & 17.26 & 11.67 & - \\
\hline $\begin{array}{l}\text { Mean } \\
\text { L.S.D (0.05) }\end{array}$ & 22.60 & $\begin{array}{l}4.9 \\
6.07\end{array}$ & 2.79 & 5.5 & $\underset{\star \star \star}{9.24}$ & $\underset{* *}{6.90}$ & $\underset{* *}{9.25}$ & $\underset{*}{12.74}$ & $\underset{\star \star \star}{16.42}$ & $\underset{* *}{11.32}$ & \\
\hline & 5.52 & 1.40 & 0.393 & 1.853 & 1.551 & 1.232 & 1.164 & 1.353 & 1.367 & 0.614 & \\
\hline $\begin{array}{l}\text { S x D x G } \\
\text { CV\% }\end{array}$ & 14.42 & 13.67 & 8.34 & 19.83 & $\begin{array}{c}2.88 \\
19.22\end{array}$ & 11.19 & 7.43 & 6.45 & 4.91 & $\begin{array}{l}\text { NS } \\
6.68\end{array}$ & \\
\hline
\end{tabular}

${ }^{*}$ yield advantage compared with the recommended cultivar, Sakha3 
Table (9): Average seed yield/plant (g) and seed weight (g) of some faba bean genotypes affected by sowing date during two successive seasons 2005/06 and 2006/07.

\begin{tabular}{|c|c|c|c|c|c|c|c|c|c|c|}
\hline \multirow{3}{*}{ Genotypes } & \multirow{2}{*}{\multicolumn{4}{|c|}{\begin{tabular}{cc}
\multicolumn{2}{c}{ Seed yield/plant $(\mathrm{g})$} \\
$2005 / 06$ & $2006 /$
\end{tabular}}} & \multirow{3}{*}{ Mean } & \multirow{2}{*}{\multicolumn{4}{|c|}{100 -seed weight (g) }} & \multirow{3}{*}{ Mean } \\
\hline & & & & & & & & & & \\
\hline & (ES) & (OS) & (ES) & (OS) & & (ES) & (OS) & (ES) & (OS) & \\
\hline $1561 / 492 / 2002$ & 20.07 & 13.07 & 28.9 & 23.83 & 21.46 & 82 & 73.0 & 83 & 76.33 & 78.58 \\
\hline $1566 / 574 / 02$ & 17.17 & 16.13 & 23.03 & 23.37 & 19.92 & 76.67 & 72.67 & 74.67 & 80.66 & 76.17 \\
\hline $1571 / 638 / 02$ & 18.1 & 18.33 & 24.43 & 25.47 & 21.58 & 79 & 73.0 & 87.0 & 83.33 & 80.58 \\
\hline $1618 / 837 / 02$ & 17.7 & 17.43 & 32.63 & 35.47 & 25.81 & 74.67 & 74.33 & 87.0 & 87.67 & 80.92 \\
\hline $73 / 27 / 02$ & 13.7 & 17.17 & 25.83 & 25.57 & 20.57 & 71.0 & 67.0 & 75.67 & 83.33 & 74.25 \\
\hline $81 / 35 / 02$ & 17.23 & 14.37 & 32.0 & 35.27 & 24.72 & 81.67 & 74.0 & 88.67 & 78.00 & 80.59 \\
\hline $92 / 59 / 02$ & 20.37 & 15.53 & 24.53 & 26.8 & 21.31 & 83.67 & 74.67 & 82.67 & 85.00 & 81.50 \\
\hline $96 / 67 / 02$ & 19.43 & 20.3 & 31.37 & 21.6 & 23.17 & 81.67 & 71.67 & 83.33 & 82.67 & 79.84 \\
\hline 1610/705/02 & 21.07 & 15.97 & 25.47 & 35.53 & 24.51 & 85.67 & 71.33 & 84.67 & 76.67 & 79.59 \\
\hline 1618/846/02 & 16.17 & 14.1 & 26.2 & 32.43 & 22.22 & 82.0 & 74.33 & 82.0 & 76.67 & 78.75 \\
\hline Saka 1 x Saka3 & 5.83 & 20.23 & 34.87 & 30.53 & 25.37 & 71.67 & 71.00 & 79.33 & 79.67 & 75.42 \\
\hline Saka 3 & 14. 31 & 17.63 & 24.9 & 41.8 & 24.66 & 74.0 & 76.67 & 86.67 & 88.33 & 81.42 \\
\hline Mean & 17.60 & 16.52 & 27.84 & 22.86 & 22.94 & 78.64 & 72.81 & 82.89 & 81.53 & 78.97 \\
\hline L.S.D $(0.05)$ & $* *$ & $*$ & $* *$ & $* *$ & $\star \star *$ & * & NS & ** & ** & $* *$ \\
\hline Genotypes(G) & 3.712 & 4.181 & 5.024 & 4.731 & 2.125 & 8.984 & 10.349 & 4.049 & 5.973 & 3.698 \\
\hline Seasons (S) & & & & & 3.376 & & & & & 1.851 \\
\hline Sowing date (d) & & & & & NS & & & & & NS \\
\hline $\mid \begin{array}{l}S \times d \\
S \times G\end{array}$ & & & & & 3.005 & & & & & $\begin{array}{l}\text { NS } \\
5.32\end{array}$ \\
\hline $\begin{array}{l}S \times G \\
D \times G\end{array}$ & & & & & 3.050 & & & & & 5.23 \\
\hline$S \times d \times G$ & & & & & 4.25 & & & & & NS \\
\hline C.V\% & 12.49 & 14.94 & 10.65 & 9.34 & 11.42 & 6.75 & 8.39 & 2.88 & 4.33 & 5.77 \\
\hline
\end{tabular}

3945 
J. Agric. Sci. Mansoura Univ., 34 (4): 3929 - 3942, 2009 